\title{
PELATIHAN PEMBUATAN TAS TALI KUR SEBAGAI PEMBERDAYAAN PEREMPUAN DI DESA PUHSARANG KECAMATAN SEMEN KABUPATEN KEDIRI
}

\author{
Kuni Nadliroh' ${ }^{1)}$, Rafita Dewi ${ }^{2)}$ \\ ${ }^{1)}$ [Teknik Mesin / UN PGRI Kediri) \\ ${ }^{2)}$ [Pendidikan Matematika / UN PGRI Kediri) \\ Rafita.devi06@yahoo.co.id \\ kuninadliroh11@gmail.com
}

\begin{abstract}
ABSTRAK
Desa Puhsarang Kecamatan Semen Kabupaten Kediri merupakan salah satu desa yang berada di kawasan pegunungan. sebagian besar masyarakatnya mempunyai pekerjaan sebagai petani dan para perempuan yang menjadi ibu rumah tangga, akan tetapi masih banyak penduduk yang berada di bawah garis kemiskinan, hal ini dikarenakan karena faktor geografis dan faktor pendidikan yang kurang memadai. untuk meningkatkan potensi perempuan sehingga bisa membantu meningkatkan perekonomian desa. Upaya tersebut berupaya pelatihan pembuatan tas dali bahan tali kur yang mana tali kur bisa dibeli dengan harga yang relatif murah dan mempunyai daya jual yang tinggi jika sudah berupa tas tali kur. Selain diberikan pelatihan tentang pembuatan tas tali kur para perempuan tersebut juga diberikan pelatihan menghitung biaya pembuatan tas tali kur dan harga jualnya di pasaran, serta juga diberikan pengarahan bagaimana tas tali kur bisa dijual belikan.
\end{abstract}

Kata kunci: Puhsarang, perempuan, tas tali kur

\begin{abstract}
ABSTRACK
Puhsarang Village, Semen District, Kediri is one of the villages in the mountains. Most of the people have jobs as farmers and women who become housewives, but there are still many people who are below the poverty line, this is due to geographical factors and inadequate educational factors. To increase women's potential so as to help improve the village economy. The effort is to train the manufacture of dali bag of rope material which the rope can be purchased with a relatively cheap price and have a high selling power if it is a rope bag. in addition to training on the manufacture of women's ladies bag is also given training to calculate the cost of making a strap bag and selling price in the market, and also given a briefing how the strap bag can be sold.
\end{abstract}

Keyword: Puhsarang, women, bag strap 


\section{PENDAHULUAN}

Dalam banyak kasus perempuan memang banyak mengalami permasalahan, mulai dari permasalahan mereka yang menjadi ibu rumah tangga saja dan mereka yang merangkap sebagai seorang pekerja[6]. Di era jaman sekarang masih terdapat juga sebagian perusahaan yang hanya mempercayakan pekerjaan tersebut kepada kaum laki-laki saja sehingga kaum perempuan tidak bisa mengembangkan potensi yang ada poada dirinya, sehingga perlu wadah khusus yang mampu menampung aspirasi perempuan-perempuan sehingga potensinya bisa tersalurkan dengan baik [5]. Sebagian besar pelosok di Indonesia masih menjadi polemik ada yang masih beranggapan bahwa seorang perempuan sejatinya hanya di rumah saja, tetapi di lain sisi adanya kebutuhan yang tidak cukup para lelaki saja yang bekerja maka dari itu perlu adanya motivasi dan terobosan-terobosan pemberdayaan perempuan dengan tidak meninggalkan kewajibannya sebagai seorang ibu rumah tangga artiya pekerjaan tersebut hanya dikerjakan saat waktu luang yaitu saat pekerjaan rumah tangga sudah terselesaikan[11]. peran perempuan bisa dalam segala aspek yaitu aspek, pendidikan, sosial ekonomi, hukum, politik, dan lain-lain. hal tersebut tentunya tidak terlepas dari kemajuan budaya bangsa yang harus diimbangi dengan peningkatan peran setiap warganya. akan tetapi tidak sedikit perusahaan yang masih menempatkan perempuan di bawah laki-laki, hal ini disebabklan

1. Pemikiran serta pemahaman tentang persamaan gender belum merata

2. Dalam dunia pendidikan belum dimasukkan pemahaman mengenai kesetaraan gender[3].

Secara sederhana makna peran dapat diartikan menjadi beberapa pemahaman,

a. Peran yang berarti suatu tindakan yang terpola yang terletak pada seputaran hak dan kewajiban.

b. Peran yang berada pada status yang dipengaruhi oleh orang lain.

c. Peran yang dilaksanakan sesuai dengan pola pikir sosial budaya yang terpikir oleh pelaku.

d. Peran yang merupakan tindakan baik atau buruk yang menyangut kesetaraan gender

Ada beberapa peran yang bisa dijalankan oleh kaum perempuan yaitu: 
1. Peran tradisi, dimana peran ini menempatkan wanita yang hidup menjadi kodratnya yaitu melahirkan memasak dan mengurus rumah tangga.

2. Peran transisi, merupakan peran yang menempatkan wanita pada seorang wanita karir akan tetapi juga tidak mengesampingkan peran tradisi.

3. Peran egalitarian, yaitu peran yang menempatkan seorang wanita menjadi wanita karir.

4. Peran kontemporer, merupakan peran yang menempatkan wanita menjadi seorang yang mandiri dalam kesendiriannya[2].

5. Peran seks, dalam peran ini peran seoranmg wanita memiliki kesetaraan dalam ranah keluarga[1]

Di Indonesia ada seorang pahlawan wanita yang sangat memperjuangkan persamaan gender yaitu ibu kita kartini yang merupakan seorang perempuan yang murni menjadi perempuan akan tetapi pada akhirnya bisa mengenyam bangku sekolah [4], selain itu ada Cut Nyak Dien yang ikut serta berjuan melawan penjajah asing [7].

Pemberdayaan perempuan seyogyanya harus dimulai dari diri mereka sendiri, akan tetapi banyak kendala yang mereka alami, bisa karena faktor pendidikan maupun kemiskinan[8]. Sejak adanya konferensi wanita yang pertama pada tahun 1975 di Mexico masalah utama yang menjadi acuan persamaan gender adalah masalah pendidikan. pada konferensi wanita keempat yang dilaksanakan di Beijing pelatihan dan pendidikan perempuan dirumuskan dalam langkah-langkah sebagai berikut:

1. Menjamin persamaan akses pendidikan

2. Adanya penghapusan buta aksara pada kaum wanita

3. Memperbaiki akses wanita dalam hal keterampilan, sains, dan teknologi yang berkelanjutan.

4. Melakukan pengembangan pendidikan yang berkelanjutan.

5. Memberikan alokasi dana yang cukup untuk implementasi dan memonitor pembaharuan[8]. 


\section{METODE PELAKSANAAN}

Pengabdian Masyarakat ini dilaksanakan pada 25 dan 26 Februari 2018 di kediaman Bapak Nur Ali Desa Puhsarag Kecamatan Semen Kabupaten Kediri. Adapun sasaran Pengabdian Masyarakat ini adalah para ibu rumah tangga pra sejahtera yang tidak mempunyai kegiatan selain mengurus rumah tangga. adapun uumlah peserta yang hadir sebanyak 19 peserta pada tanggal 25 Februari 2018 dan sebanyak 17 peserta pada tanggal 26 Februari 2018. alat dan bahan

Tali kur (warna sesuai selera), gunting untuk memotong tali kur, korek api untuk menyambung, resleting untuk penutup tas yang panjangnya sesuai dengan panjang tas tali kut yang dibuat, kain katun yang warnanya disesuaikan dengan warna talikur yang digunakan untuk melapisi bagian dalam tas, benang dan jarum untuk menyulam bahan tas.

Adapun tahapan pelaksanaan pengabdian kepada masyarakat ini adalah:

1.Tutor memberikan contoh beberapa macam simpul

2.Peserta belajar membuat simpul

3.Tutor memberikan contoh menganyam tali kur

4.Peserta belajar menganyam tali kur sampai menjadi sebuah tas

5.Tutor mmberikan pengarahan jumlah biaya yang dihabiskan untuk membuat satu tas tali kur beserta pertimbangan harga jual dan laba yang diperoleh.

Tabel daftar acara pengabdian masyarakat

\begin{tabular}{|c|c|c|c|}
\hline No & Tanggal & Kegiatan & Waktu \\
\hline 1 & \multirow[t]{4}{*}{25 februari 2018} & Pembukaan & 08.00-08.30 \\
\hline 2 & & Sambutan tuan rumah & 08.30-09.00 \\
\hline 3 & & Sambutan dari ketua pelaksana & $09.00-09.30$ \\
\hline 4 & & Pelatihan pembuatan tali kur & $09.00-13.00$ \\
\hline 5 & \multirow[t]{4}{*}{26 Februari 2018} & Pelatihan pembuatan tas tali kur & $08.00-12.00$ \\
\hline 6 & & Istirahat & $12.00-13.00$ \\
\hline 7 & & $\begin{array}{l}\text { Pelatihan penghitungan biaya dan } \\
\text { laba pembuatan tas tali kur }\end{array}$ & $13.00-14.00$ \\
\hline 8 & & penutupan & $14.00-14.30$ \\
\hline
\end{tabular}




\section{HASIL DAN PEMBAHASAN}

Seni kerajinan makrame adalah seni kerajinan menggunakan tali sebagai bahan dasarnya dan merupakan salah satu cabang seni rupa terapan. pengabdian masyarakat ini merupakan pengabdian masyarakat yang berbasis pemberdayaan perempuan yang berekonomi lemah dan tidak mempunyai pekerjaan apapun kecuali mengurus rumah tangga. bahan utama pembuatan tas ini adalah tali kur, selain harganya yang relatif murah tali kur juga mudah untuk didaptkan. Pengerjaan satu tas tali kur membutuhkan waktu kurang lebih 2 hari. setelah dianyam tali kur bisa dipadupadankan dengan rantai ataupun dengan tali yang lain sehingga menambah tingkat keindahan dan meningkatkan harga jual. Pemasaran tas tali kur bisa dititipkan ke toko-toko maupun dijual sendiri baik secara offline maupun online. kelebihan dari tas tali kur ini adalah jika dilihat dari segi bahan merupakan bahan yang sangat kuat sehingga lebih awet dan bisa digunakan untuk membawa beban yang cukup berat (tergantung dari tali yang digunakan), jika dilihat dari segi keindahannya pun menarik karena bisa dibuat motif dan warna sesuai keinginan. akan tetapi kelemahan dari tali kur ini adalah waktu pembuatan yang relatif lama, rumit dan perlu ketelitian dan kesabaran yang tinggi.

Pelatihan ini diawali dengan pengarahan beberapa simpul oleh tutor dan ditirukan oleh peserta yang hadir. ada beberapa macam jenis simpul yang diajarkan yaitu, simpul kepala, simpul rantai, simpul mati, simpul tunggal, simpulganda, simpul gordin, dan simpul jangkar.

setelah para peserta sudah bisa membuat simpul maka dilanjutkan merangkai setiap simpulyang dibuat menjadi satu lembaran yang menjadi satu sisi dari sebuah tas, setelah sisi-sisi tersebut selesai selanjutnya adalah merangkanya menjadi satu yang juga dipadukan dengan kain untuk lapisan dalam, resleting serta tali tasnya. 
Berikut merupakan rincian dana yang digunakan untuk membuat satu tas tali kur berukuran $15 \mathrm{~cm} \times 7 \mathrm{~cm} \times 12 \mathrm{~cm}$ :

Tabel Rincian biaya dan laba tas tali kur

\begin{tabular}{|l|l|l|}
\hline No & \multicolumn{1}{|c|}{ Nama Bahan } & \multicolumn{1}{|c|}{ Harga } \\
\hline 1 & Tali kur & Rp. 12.500 \\
\hline 2 & Kain puring & Rp. 20.000 \\
\hline 3 & Rantai(tali tas) & Rp. 15.000 \\
\hline 4 & Gantungan tas & Rp. 1000 \\
\hline Total & Rp. 48.500 \\
\hline Harga Jual di toko & Rp. 150.000 sampai Rp. 200.000 \\
\hline Keuntungan & Rp. 101.500 sampai Rp. 151.500 \\
\hline
\end{tabular}

dari asumsi modal serta laba yang didapatkan dari penjualan tas tali kur di atas jika dilihat dari sudut pandang tempat tinggal mereka di pedesaan maka sangat membantu perekonomian keluarga, diharapkan ada ide untuk membentuk lembaga yang mewadahi aspirasi dan kerja kecil seperti ini sehingga aspirasi mereka bisa tersalurkan dan meningkatkan daya hidup masyarakat desa puhsarang pada khususnya.

Kegiatan pelatihan pembuatan tas tali kur ini merupakan salah satu upaya untuk mengalihkan peran tradisi perempuan menjadi peran transisi sehingga bisa meningkatkan perekonomian keluarga tanpa meninggalkan kewajiaban para wanita sebagai ibu rumah tangga[9], Selain itu kegiatan ini merupakan salah satu upaya emansipasi wanita, dimana emansipasi sendiri merupakan salah satu upaya pengentasan kemiskinan dengan cara persamaan gender antara laki-laki dan perempuan. Sedemikian sehingga emansipasi wanita dapat diartikan sebagai suatu proses pelepasan diri para wanita dari kedudukan sosial ekonomi yang rendah. Atau pengekangan hukum yang membatasi adanya kemungkinan untuk berkembang dan maju dalam suatu bidang atau hal-hal tertentu. di Indonesia emansipasi dugawangi oleh R. A Kartini yang mana peranannya bisa kita rasakan sampai saat ini. Gerakan emansipasi wanita yang digalakkan Kartini adalah upaya untuk mendapatkan hakhaknya untuk memperoleh pendidikan yang layak dan sejajar dengan kaum lakilaki, sehingga kaum wanita diakui kecerdasannya dan diakui di dunia pekerjaan 
sebagaimana kaum pria. Adapun dampak emansipasi wanita yang bisa dirasakan oleh kaum perempuan di Indonesia adalah:

1. Efek depan emansipasi efek depan emansipasi ini merupakan efek yang dirasakan oleh perempuan dalam hal politik kedudukannya setara dengan kaum laki-laki.

2. Efek belakang emansipasi wanita adanya para wanita yang bekerja sepadan dengan para laki-laki

3. Efek samping emansipasi emansipasi wanita bisa disalahgunakan oleh kaum perempuan saat para perepuan tersebut telah menduduki jabatan tertentu.

4. Wanita menjadi lebih cerdas

5. Berkurangnya pelecehan dan kekerasan pada wanita

6. Dihapuskannya perbudakan wanita[10]. Adapun target yang diharapkan melalui adanya pengabdian masyarakat ini adalah:

1. Para ibu rumah tangga mempunyai kepercayaan diri yang tinggi

2. Para ibu rumah tangga bisa membuat tas yang berasal dari tali kur

3. Para ibu rumah tangga mampu memasarkan tas tali kur hasil buatannya sendiri

4. Para ibu rumah tangga mampu menghasilkan uang sebagai dukungan perekonomian keluarga

Melalui kegitan ini diharapkan mempunyai luaran dari pelaksanaan program pengabdian kepada masyarakat adalah:

1. Tumbuhnya kepercayaan diri yang tinggi pada diri perempuan

2. Para ibu rumah tangga mengetahui cara membuat tas dari tali kur

3. Para ibu rumah tangga mampu membuat dan memasarkan tas dari tali kur

\section{KESIMPULAN}

Masyarakat Desa Puhsarang sangat antusias dalam mengikuti acara tersebut, sehingga acara bisa terlaksana dengan baik. para peserta telah bisa membuat tas tali kur serta telah memasarkannya lewat akun facebook dan instagram yang telah dimilikinya. 


\section{UCAPAN TERIMA KASIH}

Terimakasih saya ucapkan kepada Bapak M. Taufik selaku Kepala Desa dari Desa Puhsarang beserta jajarannya serta Bapak Nur Ali yang telah bersedia menyediakan tempat sehingga acara ini bisa terlaksana dengan baik.

\section{DAFTAR PUSTAKA}

Abercrombie, dkk, 2010, Kamus Sosiologi, Pustaka Ajar, Yogyakarta.

Ahdiah, Indah, 2013, Peran-Peran Perempuan Dalam Masyarakat, Jurnal Academica, Untad, Vol 05 No 02. 1085-1092

Aida, Hubeis, 2010, Pemberdayaan Perempuan dari Masa ke Masa, IPB Perss, Bogor

Chuzaifah, Yunianti, 2010, Tafsir perempuan kartini, Gatra no 23 Tahun XVI 1521

Faqih, mansour, 1996, Analis gender dan Transformasi Sosial, Pustaka Pelajar, Yogyakarta

Hadiz, Liza, 2004, Perempuan dalam Wacana Politik Orde Baru, LP3S, Jakarta

Kurniasih, Imas, 2008, Perempuan Pemicu Perang, Pinus Book Publisher, Yogyakarta

Onny S. Prijono Dan A.M.W.Pranarka, 1996, Pemberdayaan Konsep Kebijakan Dan Implementasi, Cetakkan I : Center For Strategic And Internationalstudies (CSIS), Jakarta

Ritzer Dkk, 2004, Teori Sosiologi Modern, Kencana, Jakarta

Sunyoto, 2006, Pembangunan dan pemberdayaan Masyarakat, Cetakan 2, AlQaprint Jatinangor, Sumedang

Suyono, Haryono, 2003, Ekonomi Keluarga Pilar Utama Keluarga Sejahtera, Yayasan Damandiri, Jakarta 